\title{
Analisis Struktur Eksperiensial Pada Terjemahan Unsur Post- Modifier Dalam Kelompok Nomina Dan Dampaknya Terhadap Kualitas Terjemahan Dalam Buku To Bee or Not To Bee Karya John Penberthy
}

Yulita Rusli Rahmawati

Postgraduate Program of Universitas Sebelas Maret, Surakarta, Indonesia zourajulietta@gmail.com

\section{Article Info}

\section{Article history:}

Submitted March 29, 2018

Revised May 4, 2018

Accepted May 11, 2018

Published November 21, 201x

\section{Keywords:}

Post-modifier

Nominal group

Translation techniques

Systemic Functional Linguistics

Translation quality

\begin{abstract}
This research aims to determine the forms of post-modifier on nominal group, the use of translation technique, and the impact of the translation technique to the translation quality in the book To Bee or Not to Bee. The elements have their roles and functions experientially. In order to get the aspect of readability of the nominal group, the translator must have understanding of how the nominal group is formed based on the experiential structure. This research uses descriptive and qualitative based on Systemic Functional Linguistics Approach. The data collecting techniques used in this research are criterion- based sampling and document analysis by using document analysis, questionnaire and interview in order to obtain the data by giving some questions to the informants. The results of this research show that there are 536 used in this research which consist of non-finite clauses such as relative clauses, participle clauses (past and present) and to-infinitive. The results show there are 124 data $(59,61 \%)$ unchanged, 78 data $(37,50 \%)$ shifting and 6 data $(2,89 \%)$ untranslated. Adjective phrases consist of 54 data $(10,08$ $\%)$ with 39 data $(72,22 \%)$ unchanged, 14 data $(25,93 \%)$ shifting and 1 data $(1,85 \%)$ untranslated. Preposition phrases consist of 274 data $(51,11 \%)$ with 143 data $(52,19 \%)$ unchanged, 97 data $(35,41 \%)$ shifting and 34 data $(12,40 \%)$ untranslated. The applications of the translation techniques used in this research are single techniques, double techniques, and triple techniques. They have impacts to the translation quality especially in the forms of post-modifier in the nominal groups.
\end{abstract}

Corresponding Author:

Yulita Rusli Rahmawati,

Postgraduate Program of universitas Sebelas Maret, Surakarta, Indonesia,

Universitas Sebelas Maret

Jl. Ir. Sutami 36 A, Kentingan, Surakarta, Indonesia.

Email: zourajulietta@gmail.com

\section{PENDAHULUAN}

Dalam memahami konsep mengenai teori kebahasaan, linguistik sistemik fungsional berperan penting memberikan kontribusi dalam fungsi kebahasaan yang mencakup tiga aspek, dan menekankan pada metafungsi bahasa, yaitu adanya keterkaitan antara teks dan konteks. Artinya, semua bahasa memerankan fungsi secara bersamaan, yaitu fungsi eksperiensial atau ideasional, yang menceritakan tentang peristiwa yang terjadi, serta pengalaman pemakai bahasa. Fungsi yang kedua ialah fungsi interpersonal, dimana fungsi tersebut menunjukkan bahwa bahasa digunakan sebagai alat untuk berinteraksi dengan yang lain. Disisi lain, teori linguistik sistemik fungsional memandang 
bahasa dari tiga unsur, yaitu semantik, tata bahasa, dan fonologi atau grafologi. Bahasa tersebut dapat dihubungkan dalam hal arti, bentuk, dan ekspresi untuk merealisasikan arti tersebut, yang bersifat alamiah berdasarkan konteks sosial.

Selain penggunaan bahasa yang bersifat fungsional, bahasa juga bersifat kontekstual. Hal ini menunjukkan bahwa bahasa dapat merealisasikan dan direalisasikan di luar konteks lokasi pemakaian bahasa yang digunakan. Menurut Halliday \& Martin, (1993: 22), terjadi hubungan timbal balik yang menguntungkan antara teks dan konteks sosial, artinya, bahasa dapat mengekspresikan konteks, begitu pula konteks dapat pula mendeskripsikan bahasa. Konteks yang dimaksud disini ialah konteks mengenai budaya dan situasi pemakaian bahasa. Dalam teori linguistik sistemik fungsional, konteks dibagi menjadi dua, yaitu konteks linguistik dan konteks sosial, dimana konteks linguistik merujuk pada bahasa itu sendiri, sedangkan konteks sosial terbagi lagi menjadi 3, yang pertama ialah konteks situasi (register) yang mencakup medan wacana (field), pelibat wacana (tenor), dan sarana atau modus wacana (mode). Kedua ialah konteks budaya (genre), dan selanjutnya ialah konteks ideologi (ideology).

Hubungan antara teks dan konteks sangat erat kaitannya dengan bidang penerjemahan. Aktivitas penerjemahan selalu melibatkan setidaknya dua bahasa dan dua budaya yang berbeda. Dalam kegiatan penerjemahan, seorang penerjemah hendaknya memiliki pengetahuan mengenai bahasa dan budaya, baik dalam bahasa sumber maupun bahasa sasaran. Hal ini sangat penting karena dalam proses penerjemahan, seorang penerjemah dituntut untuk tidak hanya mampu dalam menerjemahkan bahasa, namun juga mampu menyampaikan pesan yang baik, termasuk dalam hal gaya dan budaya.

Bentuk bahasa dapat direalisasikan melalui penggunaan kata, frasa, klausa atau kalimat yang memiliki struktur dan sistem terbentuknya bahasa tersebut sehingga dapat diekspresikan dan digunakan sebagaimana mestinya oleh pemakai bahasa. Hal tersebut sesuai dengan konsep dalam teori linguistik sistemik fungsional yang menekankan pada fungsi kebahasaan. Struktur kebahasaan yang direalisasikan oleh berbagai macam bentuk tersebut seringkali diungkapkan dan direalisasikan melalui bentuk tulisan (grafologi), misalnya buku, novel, cerita pendek, puisi, dan sebagainya. Namun, perlu diketahui bahwa bahasa sebagai semiotik sosial terjadi dari tiga unsur atau tingkatan seperti yang telah diuraikan oleh penulis di atas, yaitu arti, bentuk, dan ekspresi. Secara umum, ketiga unsur tersebut dapat terpenuhi apabila dalam penggunaannya sesuai dengan sistem yang tepat, dimana arti direalisasikan oleh bentuk, dan selanjutnya bentuk direalisasikan oleh ekspresi. Contohnya, buku yang digunakan sebagai lokasi penelitian oleh penulis, dapat merepresentasikan penggunaan bahasa yang bersifat fungsional, dimana penulis buku To Bee or Not to Bee merealisasikan peristiwa yang terjadi di dalam kehidupan pribadinya sehingga mencapai proses pemahaman arti yang kemudian direalisasikan dalam bentuk tulisan (grafologi) yang bersifat ekspresif.

Sebelum membahas lebih lanjut tentang kelompok nomina, perlu diketahui bahwa menurut teori Halliday (1994: 24), terdapat konsep tingkatan antara kalimat, klausa, kelompok kata, kata, dan morfem. Kalimat dapat terdiri dari satu klausa atau lebih, sedangkan klausa terdiri dari satu kelompok kata atau lebih. Kelompok kata terdiri dari satu kata atau lebih, dan kata terdiri dari satu morfem atau lebih. Dari konsep Halliday tersebut, kelompok kata dapat didefinisikan sebagai unit gramatikal yang lebih kecil dibandingkan dengan klausa, bahkan terkadang lebih besar dari kata. Halliday menegaskan bahwa definisi kelompok kata yaitu "... a word complex-that is, a combination of words built up on the basis of a particular logical relation" (1994: 180). Dari pengertian tersebut, dapat berarti bahwa setiap kelompok kata memiliki elemen inti dimana elemen tersebut merupakan pusat dari setiap jenis kelompok kata. Misalnya, yang menjadi elemen inti dari kelompok nomina ialah "kata benda". 
Kelompok kata dan frasa memiliki perbedaan menurut kerangka teori Halliday. Kelompok kata ialah perluasan dari kata, yang dianggap sebagai „kata kompleks", sedangkan frasa ialah bentuk singkat dari klausa, yang juga disebut sebagai konstruksi kata-kata yang berjajar. Dilihat dari fungsinya, kelompok kata memiliki fungsi yang sama dengan kategori (misalnya, Nomina, Verba, Adverbia, dan Ajektiva), yang juga dapat menjadi kata inti. Sedangkan frasa dapat berfungsi sebagai Predikator dan memiliki Pelengkap. Namun dalam teori Linguistik Sistemik Fungsional, kelompok nomina juga disebut dengan frasa nomina (Halliday, 1985a; Matthiessen, 1992/1995; Martin, 1992; Halliday \& Mathissen, 2004 dalam Wiratno, 2011). Kelompok nomina juga didefinisikan oleh Halliday (2004) sebagai kombinasi kelompok kata yang berfungsi sebagai nomina untuk mengekspresikan wujud atau entitas tertentu. Dalam klausa, kelompok nomina dapat menduduki fungsi sebagai subjek atau komplemen, dan juga sebagai partisipan (struktur eksperiensial).

Dilihat dari sudut pandang eksperiensial, kelompok nomina mengandung dua unsur, yaitu: (1) unsur inti (Head) atau yang sering disebut dengan Benda (Thing), dan (2) unsur atau unsur-unsur Penjelas yang dapat berupa Numeratif (Numerative); Penjenis (Classifier), Pendeskripsi (Ephitet), Penegas (Qualifier), dan Deiktik (Deictic) (Wiratno, 2011: 103). Sedangkan menurut Khalid Shakir Hussein dalam makalahnya, menyatakan bahwa unsur-unsur dalam struktur kelompok nomina dibagi menjadi lima elemen, yaitu Head, Deictic, Numerative, Ephitet, dan Qualifier (2012: 7). Unsur-unsur tersebut merupakan unsur yang biasa terdapat dalam frasa maupun kalimat.

\section{TEORI DAN METODOLOGI}

Dalam penelitian ini, peneliti menggunakan suatu kajian deskriptif untuk menganalisis data yang diambil dari sebuah buku yang berjudul To Bee or Not to Bee karya John Penberthy. Penelitian ini mengaplikasikan metode kualitatif karena disamping didukung oleh adanya teori- teori yang dijadikan landasan berpikir, penelitian ini menitikberatkan pada deskripsi, yang berkaitan dengan kegiatan ontologis, dimana data yang dikumpulkan berupa kata-kata, kalimat atau gambar yang memiliki arti lebih (Sutopo, 2002: 3).

Menurut Lincoln \& Guba (1985) dalam Sutopo (2002: 3), penelitian kualitatif mampu memperlihatkan secara langsung hubungan transaksi antara peneliti dengan yang diteliti yang memudahkan pencarian kedalaman makna, karena peneliti berusaha untuk menganalisis data sedekat dan sealamiah mungkin dari berbagai perspektif sehingga mendapatkan hasil analisis yang realistis dan multiperspektif. Selain itu, penelitian ini merupakan studi kasus terpancang, dimana peneliti sudah menentukan dari awal mengenai masalah dan fokus penelitian, yaitu kualitas penerjemahan post-modifier dalam struktur eksperiensial kelompok nomina. Orientasi penelitian ini ialah pada produk atau hasil terjemahan yang dapat dilihat dari kualitas terjemahan buku To Bee or Not to Bee.

Pendekatan yang digunakan dalam penelitian ini adalah Linguistik Sistemik Fungsional (LSF), yang mengkaji tidak hanya mengenai struktur bahasa melainkan bagaimana bahasa tersebut digunakan jika dilihat dari sudut pandang LSF. 


\section{HASIL DAN PEMBAHASAN}

Hasil penelitian ini memaparkan bagaimana struktur eksperiensial unsur postmodifier dalam kelompok nomina yang terdapat dalam $\mathrm{BSu}$ mempengaruhi hasil terjemahan pada BSa. Hal tersebut dapat dilihat dari bentuk-bentuk post- modifier yang muncul dalam kelompok nomina beserta teknik-teknik yang digunakan dalam proses penerjemahan unsur post-modifier dalam kelompok nomina. Artinya, tidak semua kelompok nomina yang mengandung unsur post- modifier diterjemahkan ke dalam bentuk atau struktur yang sama ke dalam Bsa.

Berdasarkan klasifikasi tersebut, peneliti menemukan berbagai bentuk postmodifier yang terdiri dari frasa preposisi, klausa non-finite atau konstruksi "yang" berupa bentuk participle (present dan past), to infinitive atau bare infinitive, dan frasa ajektiva. Dalam fungsinya sebagai modifier pada kelompok nomina, frasa preposisi mendominasi posisi sebagai post-modifier.

Teknik yang digunakan dalam menerjemahkan Bsu ke dalam Bsa juga beragam, diantaranya ialah teknik harfiah, amplifikasi linguistik, kesepadanan lazim, peminjaman (murni dan penyesuaian), modulasi, reduksi, transposisi, kompensasi, adaptasi, variasi, generalisasi, partikularisasi, dan kalke. Namun pada kenyataanya, berdasarkan hasil analisis, peneliti mendapati beberapa teks dari Bsu yang tidak diterjemahkan ke dalam Bsa, sehingga mempengaruhi kualitas terjemahan menjadi tidak akurat, tidak berterima, dan tidak terbaca.

Dalam buku tersebut, terdapat beberapa unsur post-modifier dalam kelompok nomina yang mengalami perubahan atau pergeseran bentuk, sehingga terdapat kemungkinan akan berdampak pada perubahan atau pergeseran makna. Namun, hasil dari penelitian ini hanya akan menyajikan hasil perubahan atau pergeseran tersebut secara struktural dari BSu ke dalam BSa.

Bentuk post-modifier yang berupa frasa preposisi, klausa non-finite yang berupa konstruksi "yang", participle (present dan past), to infinitive atau bare infinitive, dan frasa ajektiva. Dari hasil penelitian, ditemukan sejumlah 208 data $(38,81 \%)$ dari data yang di analisis berupa klausa non-finite. Dari bentuk klausa tersebut terdiri dari klausa relatif, klausa participle (past dan present), dan to- infinitive. Dari temuan hasil penelitian tersebut, ditemukan sejumlah 124 data $(59,61 \%)$ yang tidak berubah bentuk atau tetap, sedangkan bentuk yang berubah ditemukan sejumlah 78 data $(37,50 \%)$. Selanjutnya, terdapat sejumlah 6 data (2,89\%) yang tidak diterjemahkan ke dalam BSa.

Bentuk post-modifier berikutnya yang ditemukan dalam penelitian ini yaitu frasa ajektiva yang ditemukan sejumlah 54 data $(10,08 \%)$. Data tersebut terdiri dari 39 data $(72,22 \%)$ yang tidak berubah bentuk ketika diterjemahkan ke dalam BSa dan sejumlah 14 data $(25,93 \%)$ yang mengalami perubahan bentuk ketika diterjemahkan ke dalam BSa. Selebihnya yaitu sejumlah 1 data $(1,85 \%)$ tidak diterjemahkan ke dalam BSa. Berikutnya, untuk data yang paling banyak ditemukan yaitu dengan bentuk frasa preposisi. Frasa tersebut ditemukan sejumlah 274 data (51,11\%), yang terdiri dari 143 data $(52,19 \%)$ yang tidak mengalami perubahan bentuk dan sejumlah 97 data $(35,41 \%)$ mengalami perubahan bentuk. Selanjutnya, ditemukan sejumlah $34 \quad(12,40 \%)$ data yang tidak diterjemahkan ke dalam BSa.

\subsection{Klausa Relatif}

Klausa relatif seringkali muncul pada tataran klausa atau kelompok kata yang memiliki unsur post-modifier. Berdasarkan fungsinya, klausa relatif memiliki kedudukan 
sebagai penegas dari unsur inti yang berupa benda. Klausa ini ditandai dengan adanya kata penghubung seperti which, who, whom, whose, that, where, when, dan why.

Berikut ini merupakan contoh analisis data kelompok nomina dengan unsur post-modifier berupa klausa relatif: Data 028/KN-PM

BSu: He knew that the colony was totally dependent on the clover and flowers [Ithat grew there]].

BSa: Ia tahu bahwa koloni benar-benar bergantung pada daun semanggi dan bungabunga [[yang tumbuh di situ]].

Tabel 1. Bentuk Post-M odifier dengan Klausa

\begin{tabular}{|l|l|l|l|l|}
\hline 047/KN-PM & \multicolumn{2}{l|}{} & No. Data \\
\hline Bahasa Sasaran (Bsa) & Bahasa Sumber (Bsu) \\
\hline $\begin{array}{l}\text { Daun } \\
\text { semanggi dan } \\
\text { bunga-bunga }\end{array}$ & NUMERATIVE/ NUMERATIF & the & DIECTIC/ DIEKTIK \\
\hline & THING/ BENDA & & NUMERATIVE/ NUMERATIF \\
\hline & CLASSIFIER/ PENJENIS & & EPITHET/ PENDESKRIPSI \\
\hline $\begin{array}{l}\text { [yang tumbuh } \\
\text { di situ] }\end{array}$ & EPITHET/ PENDESKRIPSI & CLASSIFIER/ PENJENIS \\
\hline & $\begin{array}{l}\text { Post- } \\
\text { modifier }\end{array}$ & $\begin{array}{l}\text { QUALIFIER/ } \\
\text { PENEGAS }\end{array}$ & $\begin{array}{l}\text { The clover } \\
\text { and flowers }\end{array}$ & THING/ BENDA \\
\hline & DIECTIC/ DIEKTIK & $\begin{array}{l}\text { [that grew } \\
\text { there] }\end{array}$ & Post-modifier & $\begin{array}{l}\text { QUALIFIER/ } \\
\text { PENEGAS }\end{array}$ \\
\hline
\end{tabular}

Berdasarkan tabel 1, terdapat kelompok nomina dalam BSu dan BSa yang memiliki fungsi yang sama sebagai unsur post-modifier. Hal tersebut ditunjukkan dengan adanya kelompok nomina the clover and flowers yang diterjemahkan menjadi "daun semanggi dan bunga-bunga". Oleh sebab itu, penegas yang ditunjukkan berupa bentuk klausa relatif pada BSu dan BSa menjadi tepat karena fungsinya yang menjelaskan nomina. Penanda yang menunjukkan bahwa klausa tersebut merupakan klausa relatif ialah adanya kata "that" yang mengawali bentuk klausa relatif sebagai post-modifier.

Apabila dilihat dari teknik penerjemahan yang digunakan, penerjemah dalam hal ini menggunakan teknik harfiah. Hal tersebut dapat dilihat dari hasil terjemahan pada BSa yang diartikan secara literal berdasarkan maknanya. Oleh karena itu, teknik ini dianggap cukup tepat digunakan dalam menerjemahkan kelompok nomina tersebut.

\subsection{Klausa Non-Finite}

Sama halnya dengan klausa finite, klausa non-finite juga memiliki ciri khusus, namun ciri tersebut berbeda dengan ciri yang terdapat pada klausa finite. Klausa non-finite menunjukkan adanya kata kerja yang tidak dipengaruhi oleh adanya tense dalam suatu klausa atau kelompok kata, baik past tense maupun present tense. Dalam hal ini, klausa non- finite dapat berupa relative pronoun, present participle, past participle, to infinitive atau bare infinitive, dan frasa ajektiva.

Dalam suatu klausa atau kelompok kata, verba yang bersifat non-finite tidak dapat berdiri sendiri jika dilihat secara struktural atau bersifat terikat. Berikut di bawah ini dipaparkan contoh data dalam penelitian ini yang disertai dengan penjelasannya: 


\section{Data 047/KN-PM}

BSu: Still others said the mountains

\section{[[descended to a vast ocean]].}

BSa: Yang lain lagi bilang pegunungan itu [[turun menuju lautan yang luas]].

(Tabel 2. Bentuk Post-Modifier dengan Klausa Non- Finite)

\begin{tabular}{|c|c|c|c|c|c|}
\hline \multicolumn{4}{|l|}{ 047/KN-PM } & \multicolumn{2}{|l|}{ No. Data } \\
\hline \multicolumn{3}{|c|}{ Bahasa Sasaran (Bsa) } & \multicolumn{3}{|c|}{ Bahasa Sumber (Bsu) } \\
\hline & \multicolumn{2}{|c|}{ NUMERATIVE/ NUMERATIF } & the & \multicolumn{2}{|c|}{ DIECTIC/ DIEKTIK } \\
\hline \multirow[t]{3}{*}{ pegunungan } & \multicolumn{2}{|c|}{ THING/ BENDA } & & \multicolumn{2}{|c|}{ NUMERATIVE/ NUMERATIF } \\
\hline & \multicolumn{2}{|c|}{ CLASSIFIER/ PENJENIS } & & \multicolumn{2}{|c|}{ EPITHET/ PENDESKRIPSI } \\
\hline & \multicolumn{2}{|c|}{ EPITHET/ PENDESKRIPSI } & & \multicolumn{2}{|c|}{ CLASSIFIER/ PENJENIS } \\
\hline \multirow{2}{*}{$\begin{array}{l}\text { [turun } \\
\text { menuju } \\
\text { lautan yang } \\
\text { luas] } \\
\end{array}$} & $\begin{array}{l}\text { Post- } \\
\text { modifier }\end{array}$ & $\begin{array}{l}\text { QUALIFIER/ } \\
\text { PENEGAS }\end{array}$ & mountains & \multicolumn{2}{|c|}{ THING/ BENDA } \\
\hline & \multicolumn{2}{|c|}{ DIECTIC/ DIEKTIK } & $\begin{array}{l}\text { [descended to } \\
\text { a vast ocean] }\end{array}$ & $\begin{array}{l}\text { Post- } \\
\text { modifier }\end{array}$ & $\begin{array}{l}\text { QUALIFIER/ } \\
\text { PENEGAS }\end{array}$ \\
\hline \multicolumn{4}{|c|}{ Klausa NF - Klausa NF } & \multicolumn{2}{|c|}{ Bentuk Post-Modifier } \\
\hline
\end{tabular}

Dari contoh data di tabel 2, diperoleh informasi bahwa kelompok nomina dengan unsur post-modifier yang berupa klausa non-finite di atas tersusun dari beberapa elemen pembentuk kelompok nomina dalam BSu yang dimulai dari Deiktik "the" kemudian diikuti dengan Benda "mountains". Unsur post-modifier pada tabel di atas berupa klausa non-finite yang berupa past participle yaitu

„descended". Hasil terjemahan dari BSu ke dalam BSa, penerjemah menggunakan teknik penerjemahan harfiah. Sehingga, dapat dilihat pada BSa bagaimana penerjemah menerjemahkan kelompok nomina yang mengandung unsur post- modifier tersebut diterjemahkan ke dalam BSa.

\subsection{Frasa Preposisi}

Frasa preposisi menduduki urutan pertama berdasarkan hasil penelitian. Hal tersebut dikarenakan fungsinya yang menerangkan benda yang dimaksud. Pada kenyataannya, dalam BSu frasa preposisi seringkali digunakan sebagai post-modifier atau penegas. Namun, berdasarkan fungsinya dalam suatu klausa atau kelompok kata, frasa preposisi dalam kelompok nomina tidak dapat berdiri sendiri jika dilihat dari segi struktur. Dalam contoh di bawah ini, hubungan antara frasa preposisi sebagai postmodifier dan unsur inti yang berupa nomina dapat dilihat sebagai berikut:

\section{Data 010/KN-PM}

BSu: "Let's go, Buzz, there's work [to do]." BSa: "Ayo Buzz, ada tugas untuk dikerjakan." 
(Tabel 3. Bentuk Post-Modifier dengan Frasa Preposisi)

\begin{tabular}{|c|c|c|c|c|c|}
\hline \multirow{2}{*}{\multicolumn{3}{|c|}{ 290/KN-PM }} & & \multicolumn{2}{|l|}{ No. Data } \\
\hline & \multicolumn{2}{|c|}{ Bahasa Sasaran (Bsa) } & \multicolumn{3}{|c|}{ Bahasa Sumber (Bsu) } \\
\hline & \multicolumn{2}{|c|}{ NUMERATIVE/ NUMERATIF } & the & \multicolumn{2}{|c|}{ DIECTIC/ DIEKTIK } \\
\hline \multirow[t]{3}{*}{ tugas } & \multicolumn{2}{|c|}{ THING/ BENDA } & & \multicolumn{2}{|c|}{ NUMERATIVE/ NUMERATIF } \\
\hline & \multicolumn{2}{|c|}{ CLASSIFIER/ PENJENIS } & & \multicolumn{2}{|c|}{ EPITHET/ PENDESKRIPSI } \\
\hline & \multicolumn{2}{|c|}{ EPITHET/ PENDESKRIPSI } & & \multicolumn{2}{|c|}{ CLASSIFIER/ PENJENIS } \\
\hline \multirow[t]{2}{*}{$\begin{array}{l}\text { [untuk } \\
\text { dikerjakan] }\end{array}$} & $\begin{array}{l}\text { Post- } \\
\text { modifier }\end{array}$ & \begin{tabular}{|l|} 
QUALIFIER/ \\
PENEGAS
\end{tabular} & work & \multicolumn{2}{|c|}{ THING/ BENDA } \\
\hline & \multicolumn{2}{|c|}{ DIECTIC/ DIEKTIK } & [to do] & Post-modifier & $\begin{array}{l}\text { QUALIFIER/ } \\
\text { PENEGAS }\end{array}$ \\
\hline & \multicolumn{3}{|c|}{ Frasa Preposisi-Frasa Preposisi } & \multicolumn{2}{|c|}{ Bentuk Post-Modifier } \\
\hline
\end{tabular}

Berdasarkan tabel 3, dapat diketahui bahwa kelompok nomina dengan postmodifier yang berupa frasa preposisi tersusun dari beberapa elemen diantaranya berupa deiktik, benda, dan penegas. Deiktik dapat ditunjukkan dengan adanya penanda demonstratif "the" dalam BSu yang kemudian diikuti dengan kata benda "work". Dalam hal ini, kelompok nomina tersebut tidak mengalami perubahan ketika diterjemahkan ke dalam BSa, sehingga pada struktur BSa kata benda "tugas" menjadi lebih spesifik karena penambahan penegas berupa frasa preposisi "untuk dikerjakan". Sehingga, akan lebih mudah dipahami bahwa "tugas" yang dimaksud merupakan tugas tertentu yang harus dikerjakan.

Untuk unsur Penegas atau post- modifier pada data di atas, penggunaan subjek dan verba atau adanya kesesuaian antara subjek dan predikat dapat menandakan bahwa data tersebut merupakan sebuah kalimat yang tersusun dari kelompok nomina dengan post- modifier berbentuk frasa preposisi.

Dalam struktur BSa, struktur kelompok nomina dengan unsur post- modifier juga memiliki kedudukan yang sama dengan BSu yaitu memiliki bentuk sebagai frasa preposisi dengan penanda "untuk dikerjakan".

\subsection{Frasa Ajektiva}

Frasa ajektiva memiliki pengertian secara luas yaitu konstruksi kata-kata berjajar yang terdiri dari ajektiva, yang berfungsi sebagai predikat maupun penegas. Secara umum, ajektiva berfungsi untuk menerangkan Benda atau nomina yang terdapat dalam suatu klausa atau kelompok kata. Dalam posisinya sebagai post-modifier, ajektiva dapat berupa kelompok preposisi maupun infinitive.

Lain halnya dengan frasa ajektiva, kelompok ajektiva terbentuk karena gabungan antara ajektiva dan adverbia. Dalam struktur bahasa Indonesia, biasanya adverbia pada kelompok ajektiva terletak di sebelah kiri Benda, sedangkan dalam struktur bahasa Inggris biasanya terletak sebelum ajektiva. Fungsi dari adverbia dalam kelompok ajektiva ialah menekankan pada ajektiva itu sendiri, sehingga menjadi jelas artinya karena pengaruh adverbia tersebut.

Di bawah ini merupakan contoh post-modifier yang terbentuk dari frasa ajektiva:

\section{Data 374/KN-PM}

Bsu: The wind blows like crazy, it's really cold and it's a long way [straight up].

BSa: Anginnya bertiup gila-gilaan, sangat dingin, dan jalannya [sangat jauh ke atas]. 
(Tabel 4. Bentuk Post-Modifier dengan Frasa Ajektiva)

\begin{tabular}{|c|c|c|c|c|c|}
\hline $374 / \mathrm{KN}-\mathrm{PM}$ & & & & No. Data & \\
\hline Bahasa Sasara & Bsa) & & Bahasa Sumb & su) & \\
\hline jalan & NUMERA & / NUMERATIF & $a$ & DIECTIC/ DIEK' & \\
\hline & THING/ & & & NUMERATIVE/ & JMERATIF \\
\hline & CLASSIFI & PENJENIS & & EPITHET/ PENI & SKRIPSI \\
\hline $\begin{array}{l}\text { [sangat jauh } \\
\text { ke atas] }\end{array}$ & EPITHET & NDESKRIPSI & long & CLASSIFIER/ PE & ENIS \\
\hline jalannya & $\begin{array}{l}\text { Post- } \\
\text { modifier }\end{array}$ & $\begin{array}{l}\text { QUALIFIER/ } \\
\text { PENEGAS }\end{array}$ & way & THING/ BENDA & \\
\hline & DIECTIC/ & KTIK & [straight up] & Post-modifier & $\begin{array}{l}\text { QUALIFIER, } \\
\text { PENEGAS }\end{array}$ \\
\hline
\end{tabular}

Berdasarkan tabel 4, dapat diperoleh informasi bahwa unsur post-modifier dalam kelompok nomina tersebut berupa frasa ajektiva "straight up", yang menerangkan benda "way" sebagai inti dari kelompok nomina. Kata "long" juga menandakan bahwa kata tersebut merupakan ajektiva yang memberi sifat pada benda „way", sehingga apabila dilihat dari segi makna, akan lebih spesifik dan lebih jelas jalan mana yang dimaksud.

Apabila dilihat dari sudut pandang struktur eksperiensial, pada BSu terdapat deiktik yang berupa kata sandang atau artikel "a" sebagai penanda nomina, yang diterjemahkan ke dalam Bsa menjadi „- nya". Namun, dalam hal ini terjadi pergeseran struktur deiktik dari kiri ke kanan. Hal tersebut karena perbedaan struktur eksperiensial kelompok nomina antara Bsu dan BSa. Meski demikian, perbedaan tersebut tidak menjadi masalah yang serius bagi penerjemah untuk menerjemahkan frasa ajektiva tersebut.

\section{Teknik Penerjemahan Unsur Post- Modifier dalam Kelompok Nomina}

Penggunaan teknik penerjemahan menurut Molina dan Albir (2002) setidaknya ada 18 macam teknik penerjemahan yang seharusnya digunakan oleh seorang penerjemah. Namun dalam penelitian ini, teknik yang digunakan oleh penerjemah berdasarkan hasil temuan dari analisis data yaitu sejumlah 15 teknik penerjemahan yang diterapkan. Teknik tersebut dapat dilihat dengan cara membandingkan data Bsu dan BSa, sehingga tampak bahwa teknik yang digunakan oleh penerjemah tidak hanya menggunakan satu teknik saja. Sebagian data dari penelitian ini menggunakan teknik tunggal, dan sebagian yang lain menggunakan teknik lebih dari satu. Namun, berdasarkan hasil analisis yang dilakukan oleh peneliti, peneliti menemukan bahwa teknik kesepadanan lazim yang mendominasi penggunaan teknik penerjemahan dalam buku To Bee or Not to Bee, sehingga jumlahnya lebih banyak daripada teknik yang lain. Variasi penggunaan teknik tersebut dapat dilihat pada tabel di bawah ini:

(Tabel 5. Variasi Teknik Penerjemahan dalam Buku to Bee or Not to Bee)

\begin{tabular}{|l|l|l|}
\hline $\begin{array}{c}\text { Teknik } \\
\text { Penerjemahan }\end{array}$ & Jumlah Data & \multicolumn{1}{|c|}{$\begin{array}{c}\text { Prosentase } \\
\text { Kemunculan }\end{array}$} \\
\hline Teknik Single & 394 & $73,50 \%$ \\
\hline Teknik Double & 134 & $25 \%$ \\
\hline Teknik triple & 8 & $1,5 \%$ \\
\hline Jumlah & $\mathbf{5 3 6}$ & $100 \%$ \\
\hline
\end{tabular}


Tabel 5 menunjukkan bahwa sebagian besar data dari kelompok nomina yang mengandung unsur post-modifier ialah teknik single, yaitu sejumlah 321 data. Teknik double yang diterapkan dalam penerjemahan unsur post-modifier dalam kelompok nomina pada buku yang dijadikan penelitian ini sejumlah 132 data dengan prosentase kemunculan yaitu 24,62\%. Sdangkan untuk teknik triple terdapat sejumlah 83 teknik dengan prosentase sebanyak 15,48 \% yang dterapkan pada penerjemahan unsur post- modifier dalam kelompok nomina tersebut.

Berikut ini merupakan tabel yang menunjukkan teknik penerjemahan dalam penerjemahan unsur post-modifier dalam kelompok nomina dalam buku To Bee or Not to Bee karya John Penberthy:

(Tabel 6. Teknik Penerjemahan dalam Buku To Bee or Not to Bee)

\begin{tabular}{|l|l|l|l|}
\hline No & $\begin{array}{l}\text { Teknik Penerjemahan (Menurut Molina \& } \\
\text { Albir, 2002) }\end{array}$ & $\begin{array}{l}\text { Jumlah } \\
\text { Data }\end{array}$ & $\begin{array}{l}\text { Prosentase } \\
\text { Kemunculan }\end{array}$ \\
\hline 1. & Kesepadanan Lazim & 277 & $44,39 \%$ \\
\hline 2. & Harfiah & 92 & $14,74 \%$ \\
\hline 3. & Reduksi & 86 & $13,78 \%$ \\
\hline 4. & Amplifikasi Linguistik & 67 & $10,73 \%$ \\
\hline 5. & Transposisi & 42 & $6,73 \%$ \\
\hline 6. & Modulasi & 23 & $3,68 \%$ \\
\hline 7. & Partikularisasi & 7 & $1,12 \%$ \\
\hline 8. & Peminjaman Murni & 6 & $0,96 \%$ \\
\hline 9. & Generalisasi & 5 & $0,80 \%$ \\
\hline 10. & Kompensasi & 5 & $0,80 \%$ \\
\hline 11. & Variasi & 4 & $6,64 \%$ \\
\hline 12. & Kreasi Diskursif & 3 & $0,48 \%$ \\
\hline 13. & Peminjaman Penyesuaian & 2 & $0,32 \%$ \\
\hline 14. & Adaptasi & 2 & $0,32 \%$ \\
\hline 15. & Kalke & 2 & $0,32 \%$ \\
\hline 16. & Kompresi Linguistik & 1 & $0,16 \%$ \\
\hline
\end{tabular}

Berdasarkan tabel 6, penggunaan teknik penerjemahan dalam buku "To Bee or Not to Bee" yang keberadaannya paling dominan ialah teknik penerjemahan kesepadanan lazim, dengan jumlah sebanyak 277 data dengan prosentase kemunculan sejumlah 44,39\% dari keseluruhan data. Teknik harfiah berada pada urutan kedua setelah teknik harfiah, dengan jumlah data sejumlah 92 data. Ketiga, teknik reduksi juga diterapkan dalam penerjemahan buku To Bee or Not to Bee, yang kemunculannya lbih sering dibandingkan dengan teknik amplifikasi linguistik, dengan jumah data sebanyak 86 dengan prosentase yaitu

$13,78 \%$. Teknik-teknik selanjutnya dapat dilihat pada tabel 6 dengan jumlah data beserta prosentase kemunculan data dengan teknik yang digunakan.

Penerapan teknik harfiah secara umum tidak merubah struktur atau bentuk dalam BSa, karena teknik ini merupakan teknik yang menerapkan penerjemahan kata per kata. Teknik harfiah dalam penelitian ini merupakan teknik yang paling dominan digunakan oleh penerjemah dalam menerjemahkan unsur post-modifier dalam kelompok nomina pada buku To Bee or Not to Bee. Teknik tersebut digunakan khususnya yang terdapat dalam bentuk kelompok preposisi. Meski terdapat 
kemungkinan terjadi perubahan makna semantik, teknik ini sering muncul dalam proses penerjemahan.

Penerapan teknik kesepadanan lazim juga berdampak pada ketetapan hasil terjemahan yang tidak merubah makna baik secara struktural maupun gramatikal. Teknik ini termasuk teknik yang sering muncul dalam penerjemahan kelompok nomina yang mengandung unsur post- modifier. Dalam penilaian kualitas terjemahan, teknik ini memiliki tingkat keakuratan, keberterimaan, dan keterbacaan yang cukup tinggi, mengingat adanya sedikit perubahan atau pergeseran makna maupun struktur dari Bsu ke dalam BSa.

Dampak dari teknik penerjemahan kreasi diskursif hampir sama dengan kedua teknik yang telah dijelaskan sebelumnya, yaitu harfiah dan kesepadanan lazim. Hal tersebut dikarenakan tidak terjadinya perubahan struktur atau makna yang disampaikan ke dalam BSa. Bahkan informasi atau pesan yang disampaikan dalam penggunaan teknik ini bersifat utuh dan tidak terjadi distorsi atau penyimpangan makna. Oleh karena itu, dengan adanya ketiga teknik tersebut, penerjemah tidak akan kesulitan dalam mencari padanan kata agar pesan atau informasi dapat tersampaikan dengan baik.

Penerapan teknik transposisi pada penerjemahan unsur post-modifier dalam kelompok nomina pada buku To Bee or Not to Bee sangat berdampak pada hasil terjemahan. Teknik yang merubah stuktur gramatikal ini, dapat berdampak pada pergeseran kelas kata atau mengalami perubahan bentuk baik secara leksikal maupun gramatikal. Seperti yang telah dijelaskan pada bab sebelumnya, bahwa unsur postmodifier dalam kelompok nomina yang menjadi masalah dalam penelitian ini berada pada struktur eksperiensial yang berfungsi sebagai Penegas. Oleh karena itu, perubahan bentuk atau pergeseran kelas kata sangat mungkin terjadi mengingat adanya perbedaan struktur atau kaidah dalam BSu maupun Bsa. Perbedaan tersebut secara umum diterangkan dengan pola diterangkan-menerangkan, begitu juga sebaliknya. Hal itulah yang menyebabkan penggunaan teknik transposisi berpotensi merubah hasil terjemahan yang juga berdampak pada penilaian kualitas terjemahan.

Penerapan teknik reduksi dalam menerjemahkan unsur post-modifier dalam kelompok nomina pada buku To Bee or Not to Bee juga sangat berpengaruh terhadap hasil terjemahan. Teknik ini cukup signifikan prosentase kemunculannya dalam analisis data penelitian. Meskipun teknik ini merupakan teknik penghilangan atau pengurangan bentuk atau struktur dan makna yang terkandung dalam BSu, namun kenyataannya terdapat beberapa data yang mengalami penghilangan dikarenakan teknik reduksi.

Pada penelitian ini, kemunculan teknik reduksi lebih sering terjadi pada unsur deiktik yang berupa kata sandang atau artikel, demonstratif, dan genitif. Selain itu, penghilangan terjemahan pada unsur post-modifier juga meyakinkan peneliti bahwa penerjemah menggunakan teknik reduksi ketika menerjemahkan BSu ke dalam BSa.

Teknik amplifikasi linguistik merupakan yang diterapkan pada penerjemahan dengan cara menambahkan unsur-unsur linguistik atau memberikan informasi lebih dari Bsu kepada BSa mengenai suatu istilah atau ungkapan, sehingga hasil terjemahan tersebut memiliki makna atauinformasi yang lebih luas. Dengan adanya penambahan tersebut, maka terdapat kemungkinan adanya perubahan struktur eksperiensial dari Bsu ke dalam BSa.

Penerapan teknik generalisasi digunakan untuk menerjemahkan suatu istilah atau ungkapan dari Bsu ke dalam BSa dengan mencari padanan yang lebih umum atau netral digunakan dalam Bsa. Teknik ini berpotensi merubah fungsi eksperiensial pada suatu 
istilah atau ungkapan yang diterjemahkan karena padanan tersebut. Perubahan tersebut biasanya terjadi pada unsur penjenis yang terletak di sebelah kiri benda dalam BSu dan di sebelah kanan benda dalam BSa. Sehingga, dari perubahan tersebut didapatkan makna yang lebih umum digunakan atau lebih netral dalam BSa.

Teknik partikularisasi merupakan teknik yang digunakan untuk mencari padanan kata yang lebih spesifik atau lebih khusus dalam BSa. Teknik tersebut berdampak pada hasil terjemahan karena adanya perubahan istilah atau ungkapan yang semula bersifat umum kemudian diterjemahkan menjadi lebih spesifik berdasarkan fungsi dan makna semantik yang terkandung di dalamnya.

Teknik adaptasi juga jug amerupakan teknik yang sangat berpengaruh pada hasil terjemahan dalam BSa, mengingat teknik ini merupakan teknik yang berkaitan dengan konteks budaya dalam BSu maupun BSa. Teknik ini merupakan teknik penyesuaian terjemahan istilah atau ungkapan yang disesuaikan dengan konteks budaya dalam BSa. Secara struktur eksperiensial, teknik ini tidak berpotensi menimbulkan perubahan, namun teknik ini memberikan informasi mengenai istilah atau ungkapan dalam Bsu agar mudah dipahami oleh target Bsa.

Penerapan teknik modulasi juga berdampak pada hasil terjemahan karena berpotensi menimbulkan perubahan baik secara struktural maupun makna semantisnya, karena teknik ini digunakan untuk merubah sudut pandang atau fokus yang berkaitan dengan BSu. Pada penelitian ini, terdapat contoh data penelitian yang mengalami dampak dari teknik modulasi tersebut, yaitu pada data 505/KN-PM yang menunjukkan terjadinya perubahan sudut pandang dari kelompok nomina the rest of the way to the tree menjadi pelan-pelan menuju pohon. Perubahan fokus pada BSu tersebut erpotensi merubah bentuk pada Bsa. Sedangkan teknik kompensasi juga berdampak pada terjemahan, yaitu dengan adanya penambahan unsur-unsur linguistik atau pemberian efek stilistika pada BSa mengakibatkan terjadinya perubahan fungsi eksperiensial, namun tidak terlepas dari makna yang ada.

Penerapan teknik peminjaman, baik peminjaman murni maupun peminjaman penyesuaian sangat berdampak pada hasil terjemahan, hal tersebut juga berkaitan dengan konteks budaya dari Bsu ke dalam Bsa. Apabila suatu teks yang mengandung unsur peminjaman tersebut tidak diterjemahkan dengan baik, maka akan mengakibatkan penyimpangan makna dalam Bsa. Terlebih lagi, dalam konteks budaya Bsa belum tentu dapat menerima dan memahami istilah atau ungkapan yang digunakan dalam BSu. Namun, jika dilihat dari makna semantis, penggunaan teknik peminjaman ini tidak menimbulkan dampak yang berarti pada hasil terjemahan. Hal tersebut dikarenakan kesesuaian antara istilah atau ungkapan yang dipinjam memiliki makna yang tidak menyimpang. Dengan kata lain, terdapat kemiripan antara istilah yang dipinjam dari Bsu ke dalam BSa.

Teknik variasi juga tidak berpotensi mengalami perubahan karena penyesuaian istilah atau ungkapan yang digunakan dalam BSu ke dalam BSa terhadap konteks social budaya. Sama halnya dengan teknik peminjaman dan variasi, teknik kalke juga memiliki kemungkinan kecil mengalami perubahan baik dari segi struktur maupun makna.

\section{SIMPULAN}

Terdapat beberapa bentuk unsur post-modifier yang terdapat dalam kelompok nomina dalam buku To Bee or Not to Bee, diantaranya yaitu berupa klausa relatif, klausa non-finite (past participle, present participle, dan to- infinitive), frasa preposisi, dan frasa ajektiva. Masing-masing dari unsur tersebut memiliki peran dan fungsi yang 
berbeda secara struktur eksperiensial. Dari temuan bentuk post-modifier tersebut, bentuk yang paling dominan yang ditemukan pada kelompok nomina yang terdapat dalam buku To Bee or Not to Bee ialah berupa frasa preposisi. Hal tersebut dikarenakan jumlah data yang ditemukan sejumlah 274 data dengan prosentase kemunculan sebesar 51,11 \% dari keseluruhan data yang berjumlah 536 data.

Bentuk post-modifier yang menempati urutan kedua setelah frasa preposisi yaitu berupa klausa non-finite, dengan jumlah data yang diperoleh sejumlah 208 data dan prosentase sebesar 38,81 \%. Klausa tersebut menempati posisi sebagai unsur postmodifier dengan spesifikasi non-finite. Selanjutnya, unsur post-modifier yang berupa frasa ajektiva yang ditemukan sejumlah 54 data $(10,08 \%)$ dari 536 data penelitian. Artinya, dari sejumlah bentuk yang membentuk unsur post-modifier dalam kelompok nomina yang terdapat dalam buku To Bee or Not to Bee tersebut, dapat disimpulkan bahwa frasa preposisi merupakan bentuk yang paling mendominasi sebagai unsur post-modifier atau penegas dalam kelompok nomina yang terdapat dalam buku To Bee or Not to Bee dibanding dengan unsure-unsur penegas yang lain.

Dengan adanya variasi teknik yang digunakan dalam menerjemahkan unsur postmodifier yang terdapat dalam kelompok nomina dalam buku To Bee or Not to Bee, ditemukan sejumlah 15 macam teknik, diantaranya ialah teknik harfiah, amplifikasi linguistik, kesepadanan lazim, reduksi, transposisi, peminjaman (murni dan penyesuaian), kalke, kompensasi, kompresi linguistik, generalisasi, partikularisasi, kreasi diskursif, adaptasi, modulasi, dan variasi. Teknik-teknik tersebut terbagi lagi menjadi 3 jenis penerapan yaitu penerapan 1 teknik (single), penerapan 2 teknik (double), dan penerapan 3 teknik (triple). Penerapan tersebut diaplikasikan pada semua bentuk postmodifier yang telah dijelaskan sebelumnya. Masing-masing dari penerapan teknik tersebut memiliki jumlah dan prosentase berdasarkan hasil analisis dan penghitungan.

Dari total keseluruhan data, teknik single yang diterapkan pada penerjemahan post-modifier dalam kelompok nomina yaitu sejumlah 394 data dengan prosentase sebesar 73,50 \%, sedangkan untuk teknik double yaitu sejumlah 134 data dengan prosentase sebesar $25 \%$. Kemudian untuk teknik triple diterapkan sejumlah 8 data dengan prosentase sebesar 1,5\% dari data keseluruhan.

Teknik yang diterapkan dengan menggunakan 2 teknik (double) yaitu teknik harfiah-amplifikasi linguistik ( 2 data), teknik peminjaman murni- amplifikasi linguistik (17 data), teknik harfiah-modulasi (8 data), teknik harfiah- reduksi (11 data), teknik transposisi- amplifikasi linguistik (3 data), teknik harfiah-generalisasi (2 data), teknik harfiah-transposisi (4 data), teknik reduksi-kompensasi (1 data), teknik kompensasimodulasi ( 1 data), teknik kompensasi- reduksi ( 6 data), teknik adaptasi-harfiah (1 data), teknik harfiah-kesepadanan lazim (31 data), teknik partikularisasi-harfiah (2 data), teknik reduksi-modulasi (4 data), teknik kesepadanan lazim-reduksi (13 data), teknik kesepadanan lazim- amplifikasi linguistik (7 data), teknik peminjaman murni-harfiah (1 data), teknik harfiah-variasi ( 2 data), teknik modulasi- kesepadanan lazim (1 data), teknik transposisi-kesepadanan lazim (5 data), teknik partikularisasi-amplifikasi linguistik (1 data), teknik generalisasi-reduksi (2 data), teknik amplifikasi linguistikkreasi diskursif (1 data), teknik reduksi- amplifikasi linguistik (2 data), teknik peminjaman penyesuaian-harfiah (2 data), teknik kesepadanan lazim-peminjaman murni (1 data), dan teknik peminjaman penyesuaian-reduksi (1 data).

Penerapan 3 teknik penerjemahan atau triple ditemukan sejumlah 8 data, diantaranya yaitu teknik kreasi diskursif- harfiah-kalke (1 data), teknik reduksitransposisi-variasi (1 data), teknik transposisi-amplifikasi linguistik-modulasi (1 data), teknik kalke-harfiah-adaptasi (1 data), teknik amplifikasi linguistik- peminjaman murni- 
kreasi diskursif (1 data), teknik harfiah-reduksi-kesepadanan lazim (1 data), teknik kesepadanan lazim- variasi-amplifikasi linguistik (1 data), dan teknik peminjaman murni-reduksi- kesepadanan lazim (1 data).

Berdasarkan hasil temuan penelitian, bentuk post-modifier yang ditemukan sejumlah 208 data $(38,81 \%)$ dari data yang di analisis yaitu berupa klausa non-finite. Dari bentuk klausa tersebut terdiri dari klausa relatif, klausa participle (past dan present), dan to- infinitive. Dari temuan hasil penelitian tersebut, ditemukan sejumlah 124 data $(59,61 \%)$ yang tidak berubah bentuk atau tetap, sedangkan bentuk yang berubah ditemukan sejumlah 78 data $(37,50 \%)$. Selanjutnya, terdapat sejumlah 6 data $(2,89 \%)$ yang tidak diterjemahkan ke dalam BSa. Bentuk post-modifier berikutnya yang ditemukan dalam penelitian ini yaitu frasa ajektiva yang ditemukan sejumlah 54 data $(10,08 \%)$. Data tersebut terdiri dari 39 data $(72,22 \%)$ yang tidak berubah bentuk ketika diterjemahkan ke dalam BSa dan sejumlah

14 data $(25,93 \%)$ yang mengalami perubahan bentuk ketika diterjemahkan ke dalam BSa. Selebihnya yaitu sejumlah 1 data $(1,85 \%)$ tidak diterjemahkan ke dalam BSa. Berikutnya, untuk data yang paling banyak ditemukan yaitu dengan bentuk frasa preposisi. Frasa tersebut ditemukan sejumlah 274 data (51,11\%), yang terdiri dari 143 data $(52,19 \%)$ yang tidak mengalami perubahan bentuk dan sejumlah 97 data $(35,41 \%)$ mengalami perubahan bentuk. Selanjutnya, ditemukan sejumlah $34(12,40 \%)$ data yang tidak diterjemahkan ke dalam BSa.

Dari pendekatan yang digunakan oleh peneliti, pada dasarnya penelitian ini masih belum membahas terlalu jauh mengenai teori dan pendekatan yang digunakan. Teori yang digunakan dalam penelitian ini hanya sebatas teori mengenai post-modifier yang terdapat dalam kelompok nomina. Pendekatan yang digunakan oleh peneliti juga masih sebatas mengenai pendekatan secara struktur eksperiensial. Oleh karena itu, akan lebih baik jika penelitian-penelitian selanjutnya dilakukan dengan membahas teori dan pendekatan dengan menggunakan Linguistik Sistemik Fungsional secara lebih terperinci dan lebih spesifik.

Penelitian ini juga merupakan kajian mengenai produk penerjemahan. Namun, peneliti menyadari bahwa masih terdapat banyak kekurangan dalam mengkaji terjemahan unsur post-modifier yang terdapat dalam kelompok nomina dalam buku To Bee or Not to Bee. Oleh karena itu, peneliti sangat berharap kepada peneliti berikutnya untuk dapat menyempurnakan penelitian ini guna memperkaya khasanah keilmuan khususnya di bidang penerjemahan.

Dalam menerjemahkan kelompok nomina, tidak jarang seorang penerjemah mengalami kesulitan ketika dihadapkan pada penerjemahan kelompok nomina yang memiliki struktur yang sangat kompleks. Penerjemah harus mengetahui bagaimana kelompok nomina tersebut terbentuk berdasarkan fungsi dan maknanya baik secara struktural maupun gramatikal. Oleh karena itu, ada baiknya jika seorang penerjemah tidak mengabaikan hal-hal tersebut.

Salah satu unsur yang membentuk kelompok nomina yaitu unsur Penegas, atau dalam penelitian ini digunakan istilah post-modifier. Dalam menerjemahan unsur postmodifier, seorang penerjemah sebaiknya lebih teliti dalam menentukan apakah kelompok nomina yang diterjemahkan mengandung unsur post- modifier atau tidak, dengan didasarkan pada letak dan struktur secara eksperiensial. Penerjemah juga harus lebih jeli apakah unsur post-modifier tersebut mengalami perubahan bentuk ketika diterjemahkan ke dalam BSa. Oleh karena itu, sudah seharusnya jika seorang penerjemah harus memiliki bakat atau keterampilan dalam menerjemahkan unsur post-modifier dalam kelompok nomina, sehingga dari hasil terjemahan akan terlihat bagaimana 
peran danfungsi seorang penerjemah ketika menerjemahkan suatu teks dari BSu ke dalam BSa. Penghilangan atau pengurangan dan penambahan informasi terhadap hasil terjemahan juga sangat berpengaruh terhadap kualitas terjemahan. Oleh karena itu, sebaiknya seorang penerjemah tidak melakukan hal tersebut apabila hasil terjemahan akan berdampak pada penyimpangan atau terjadinya distorsi makna.

\section{DAFTAR PUSTAKA}

Albir, A.H \& Molina, L. (2002). Translation technique revisited: A dynamic and functionalist approach. Meta, Vol. XLVII, No.4. Spain: Universitat Autonoma Barcelona.

American Psychological Association. (2010). Publication manual of the American psychological association. Sixth Edition. Washington DC: United States of America.

Arifin, Siti Salamah, dkk. (1997). Sintaksis bahasa Sindang. Jakarta: Pusat Pembinaan dan Pengembangan Bahasa.

As-Safi, A.B. (2014). Translation theories, strategies and basic theoretical issues. Jordan: Petra University.

Bassnet-McGuire. (1980). Translation studies. New York: Mathuen \& Co. Ltd.

Bell, Roger, T. (1991). Translation and translating: Theory and Practice. London: Longman.

Catford, J. C. (1965). A Linguistic theory of translation. London: Oxford University Press.

Catford, J. C.. (1978). A Linguistic theory of translation. Britain: University Press.

Crystal, David. (1976). Prosodic systems and intonation in English. Cambridge: University Pres.

Halliday, M.A.K. (2004). An introduction to functional grammar. Third Edition. London: Arnold.

Halliday, M.A.K. (1994). An introduction to functional grammar. Second Edition. London: Edward Arnold.

Halliday, M.A.K dan J.R. Martin. (1993). Writing science: literacy and discursive power. Pittsburgh: University of Pittsburgh Press.

Hussein, Khalid. S. (2012). A functional analysis of the Nominal group structures in "There Was A Saviour" by Dylan Thomas. University of Thi-Qar College of Education (http://www.iasj.net/ias)?func=ful ltext\&aId=12109) (Diunduh 9 Agustus 2014).

Kencono, Joko. (1982). Dasar-dasar linguistik umum. Jakarta: Fakultas Sastra Universitas Indonesia.

Kridalaksana. H. (1983). Kamus linguistik. Jakarta: PT. Gramedia.

Krippendorff, K. (1980). Content analysis: an introduction to its methodology. Beverly Hills, California: Sage Publication Ltd.

Kriston, Andrea. (2014). An approach to business translations. A functionalist translation. Scientific Bulletin of Politehnica University of Timişoara of Transactions on Modern Languages. Vol.13. Issue 1. Romania: Tibiscus University. 
Larson, M. L. (1984). Meaning-based translation: A guide to cross-language equivalence. Lanham Md: University Press of America.

Machali, Rochayah. (1998). Redefining textual equivalence in translation (with special reference to Indonesia-English). Jakarta: The Translation Center Faculty of Artthe University of Indonesia.

Machali, Rochayah. (2000). Pedoman bagi penerjemah. Jakarta: Penerbit Grasindo.

Moleong. L. (2010). Metodologi penelitian kualitatif. Bandung : PT Remaja Rosdakarya.

Nababan, M. Rudolf. (2003). Teori menerjemahkan bahasa Inggris. Yogyakarta: Pustaka Pelajar.

Nababan, M. R., Nuraeni, A \& Sumardiono. (2012). Pengembangan model kualitas terjemahan. Kajian Linguistik dan Sastra. Vol.24, No.1.

Newmark, Peter. (1981). Approaches to translation. New York: Pergamon Press.

Newmark, P. (1988). A Textbook of translation. New York: Prentice Hall.

Newmark, Peter. (1988). A Textbook of translation. London: Prentice Hall International.

Nichols, J. \& Woodbury, A.C. (1985). Grammar inside and outside the clause. London: Cambridge University Press.

Nida, Eugene. A. \& Taber, C.R. (1982). The theory and practice of translation. Leiden: E.J.Brill.

Nord, C. (1997). Translating as a purposeful activity: functionalist approaches explained. Manchester: St. Jerome Publishing.

Penberthy, John. (2006). To Bee or Not to Bee. Panorama Press, Incorporation.

Penberthy, John. (2009). To Bee or Not to Bee: Lebah yang bosan mencari madu. PT Gramedia Pustaka Utama.

Pramuditya, Reza. S. (2016). Analisis dampak teknik penerjemahan terhadap fungsi eksperiensial serta nilai keakuratan dan keberterimaan nominal group dalam terjemahan cerpen "The Adventure of the Veiled Lodger" (Pendekatan linguistik sistemik fungsional). Tesis. Surakarta: Universitas Sebelas Maret.

Purwaningsih, Dyah. R. (2010). Analisis teknik dan kualitas terjemahan unsur premodifier dalam kelompok nomina dalam novel The da Vinci Code Karya Dan Brown. Surakarta: Universitas Sebelas Maret.

Reginasari, Indri. (2012). Analisis kelompok nomina pada empat lirik lagu oompa loompa sebagai citraan anak nakal dalam novel Charlie and the Chocolate Factory karya Roald Dahl. Depok: Universitas Indonesia.

Samsuri. (1985). Tata kalimat Bahasa Indonesia. Jakarta: Sastra Hudaya.

Santosa, Riyadi. (2011). Logika Wacana: Analisis hubungan konjungtif dengan pendekatan linguistik sistemik fungsional. Surakarta: Sebelas Maret University Press.

Santosa, Riyadi. (2003). Semiotika sosial. Surabaya: Jawa Pos Press.

Saragih, dkk. (2006). Bahasa dalam konteks sosial: pendekatan linguistik fungsional sistemik terhadap tata bahasa dan wacana. Medan: Pascasarjana Unimed.

(http://bangpek- kuliahsastra.blogspot.com/2011/12/aliran-neo-firthian.html)

(Diunduh 16 Januari 2013) 
Spradley, J.P. (1980). Participant observation. New York, N.Y.: Holt, Rinehart, and Winston. Sutopo, H.B. (2002). Metodologi penelitian kualitatif. Surakarta : UNS Press. Hessel

Nogi .S T. 2005. Manajemen Publik. Jakarta: PT. Grasindo.

Tou, A.B. (1989). Some insights from Linguistic into the processes and problems of translation. TEFLIN Journal 1. P. 123-148

Verhaar. J.W.M. (1980). Teori linguistik dan bahasa Indonesia. Yogyakarta: Penerbit Kanisius

Wiratno, T. (2011). Pengantar ringkas sistemik fungsional linguistik (draft 2011). Surakarta: UNS.

http://arkinharrys.blogspot.com/2014/04/sistemik-fungsional-linguistik.html (Diunduh 5 Oktober 2014)

http://ihsania.blog.uns.ac.id/mengetahui- proses-dalam-sebuah- penerjemahan (Diunduh 18 Nopember 2016)

https://www.thoughtco.com/postmodifier- grammar-1691519 (Diunduh 4 Januari 2017) 